Provided for non-commercial research and education use. Not for reproduction, distribution or commercial use.

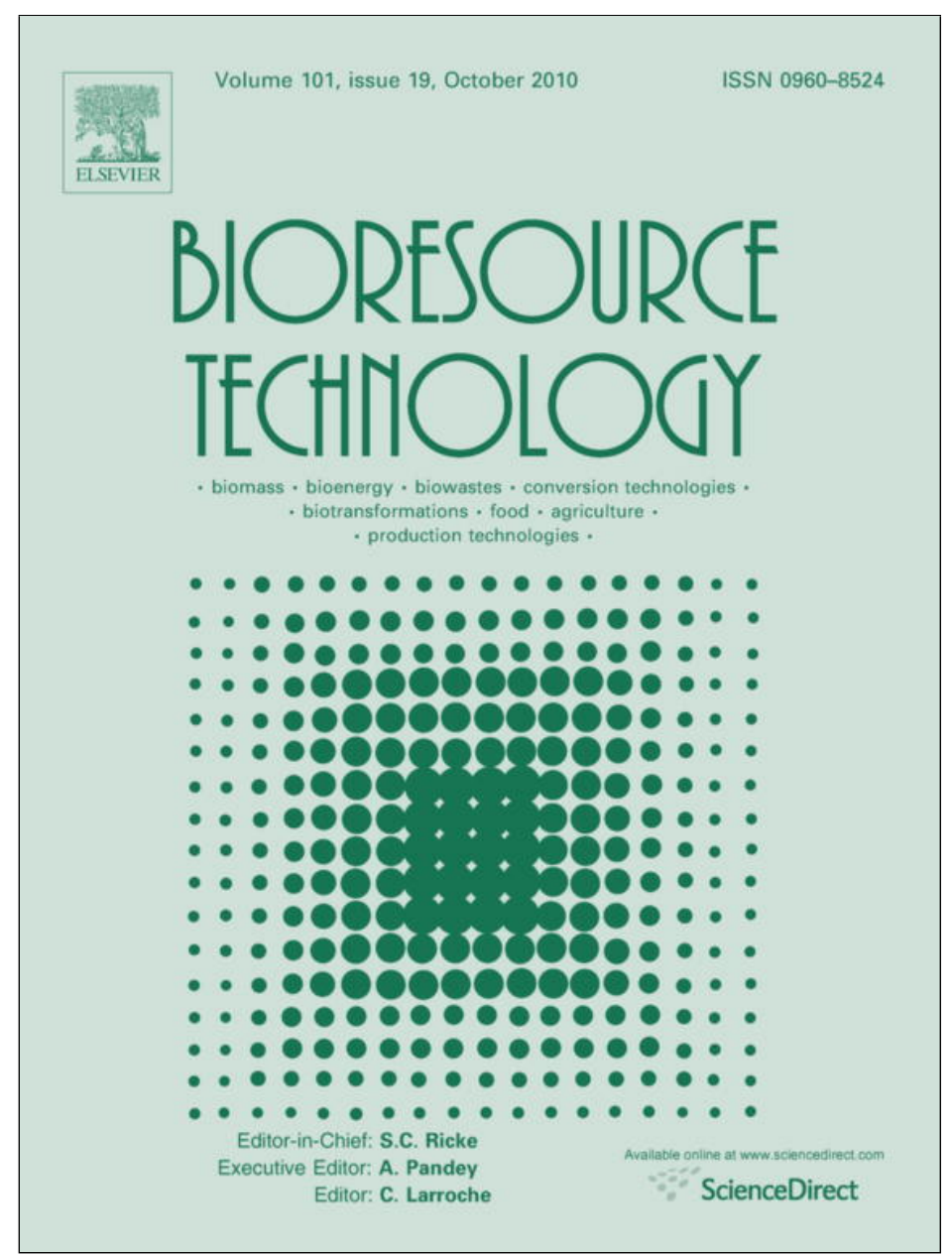

This article appeared in a journal published by Elsevier. The attached copy is furnished to the author for internal non-commercial research and education use, including for instruction at the authors institution and sharing with colleagues.

Other uses, including reproduction and distribution, or selling or licensing copies, or posting to personal, institutional or third party websites are prohibited.

In most cases authors are permitted to post their version of the article (e.g. in Word or Tex form) to their personal website or institutional repository. Authors requiring further information regarding Elsevier's archiving and manuscript policies are encouraged to visit:

http://www.elsevier.com/copyright 


\title{
Potential odour emission measurement in organic fraction of municipal solid waste during anaerobic digestion: Relationship with process and biological stability parameters
}

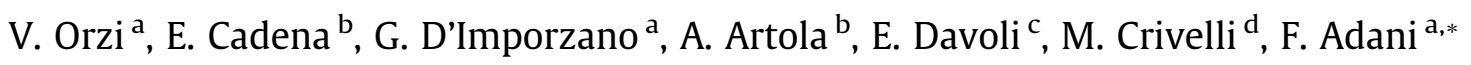 \\ ${ }^{a}$ RICICLA Group - Dipartimento di Produzione Vegetale, Università degli Studi di Milano, Via Celoria 2, 20133 Milano, Italy \\ bepartament d'Enginyeria Química - Escola d'Enginyeria - Universitat Autònoma de Barcelona, Campus Bellaterra, Cerdanyola del Vallès, 08193 Barcelona, Spain \\ ${ }^{\mathrm{C}}$ Istituto Mario Negri, Via La Masa 19, 20156 Milano, Italy \\ d PCA Technologies, Via 24 Maggio 19, 20015 Parabiago (MI), Italy
}

\section{A R T I C L E I N F O}

\section{Article history:}

Received 11 December 2009

Received in revised form 26 April 2010

Accepted 27 April 2010

Available online 23 May 2010

\section{Keywords:}

Anaerobic digestion

Biological stability

Electronic nose

GC-MS

Odours

\begin{abstract}
A B S T R A C T
The aim of the present study is to investigate the correlation between microbial activity, i.e., biological stability measured by aerobic ( $\mathrm{OD}_{20}$ test) and anaerobic tests ( $\mathrm{ABP}$ test), and odour emissions of organic fraction of municipal solid waste during anaerobic digestion in a full-scale treatment plant considering the three stages of the process (input, digested and post-digested waste).

The results obtained indicated that the stabilization of the treated material reduces the odour impact measured by the olfactometric approach. Successive application of gas chromatography mass spectrometry (GC-MS) and electronic nose (EN) allowed the characterization of the different groups of volatile organic compounds (VOCs) responsible of odour impacts determining, also, their concentration. Principal component and partial least squares analyses applied to the EN and GC-MS data sets gave good regression for the $\mathrm{OD}_{20}$ vs the $\mathrm{EN}$ and $\mathrm{OD}_{20}$ vs the GC-MS data. Therefore, $\mathrm{OD}_{20}$ reduction could be used as an odour depletion indicator.
\end{abstract}

(c) 2010 Elsevier Ltd. All rights reserved.

\section{Introduction}

Anaerobic digestion (AD) has been used for over 100 years to stabilize materials such as wastewater sludge, municipal solid waste, and other industrial refuses (Ferrer et al., 2008). In recent years, anaerobic digestion has emerged as one of the technologies of high interest because of its potential usefulness as a low-environmental impact alternative to fossil fuel energy. Anaerobic digestion provides clean fuel from renewable feedstocks (Fredriksson et al., 2006). Anaerobic digestion is a biological process in which biodegradable matter (present in the organic fraction of municipal solid waste - OFMSW, energy crops, and agro-industrial wastes) is degraded or decomposed by the activity of specific microorganisms in the absence of oxygen, producing biogas (mainly methane and carbon dioxide) that can be used for electricity generation (Lissens et al., 2001).

The establishment of an anaerobic metabolism during the AD process produces a set of compounds that could have environmental impacts mainly associated with their odourous potential (Smet et al., 1999) or with their contribution to greenhouse gases emissions (Barlaz, 2006; Moller et al., 2009). Volatile organic com-

\footnotetext{
* Corresponding author.

E-mail address: fabrizio.adani@unimi.it (F. Adani).
}

pounds (VOC) constitute the main group of odourants emitted in these types of treatment processes. Ketones, alkanes, alkenes, alcohols, acids, terpenes (pinene, cymene and limonene) and organic sulphur compounds are among the VOCs commonly reported (Smet et al., 1999; Staley et al., 2006). In addition, other odourous compounds such as hydrogen sulphide and ammonia have also been related with anaerobically digested wastes (Rosenfeld and Suffet, 2004).

However, even if odour emissions from anaerobic environments are reported in literature, most of the references on VOCs emissions are related to landfills or laboratory scale reactors, and only few of them correspond to full-scale treatment facilities. Data on VOCs emissions from aerobic treatment processes at industrial scale are easier to found (Eitzer, 1995; Komilis et al., 2004; Tsai et al., 2008). Fricke et al. (2005) compared different aspects of aerobic and anaerobic procedures for municipal solid waste treatment including exhaust emissions. These investigators highlighted the scarcity of data on emissions relating anaerobic treatments followed by aerobic processes.

In addition to the production of biogas, the AD also resulted in the production of a residual organic matrix; i.e., digestate (Tani et al., 2006; Zhang et al., 2007) that can be used in agriculture as a nutrient fertilizer and/or an organic amendment (Tambone et al., 2009). The use of digestate in agriculture, especially in open 
fields, needs to meet agronomic standards, but above all it needs to consider the concerns of the population regarding the health problems and annoyance it may cause, particularly because of the odour emission (Edelmann et al., 2005).

Anaerobic digestion leads to stabilization of organic matter (OM) as a consequence of OM degradation (Pognani et al., 2009; Tambone et al., 2009). Biological stability indicates the extent to which readily biodegradable organic matter has decomposed. Therefore, high biological stability after the anaerobic process indicates lower microbial activity in the residual waste than in the starting biomass, as substrate is no longer available. Therefore, high biological stability implies a strong reduction in odour production, as odours are produced by the microbial activity (D'Imporzano et al., 2008). In this way AD is also defined as a biological process able to reduce the environmental impacts of residual waste when it is used in open fields. To our knowledge, few data exist on the effect of $A D$ on the reduction of OFMSW odour impact, particularly to odours associated to the agricultural use of digestate. Therefore, there is a need for scientific data reporting the real odourous impact of the application of digestate in the agriculture. It is also interesting to know how the biological stabilization occurring during the $\mathrm{AD}$ process can reduce this impact.

The main objective of the present study is to evaluate the correlation between biological stability parameters and the potential odourous impacts of the OFMSW treated in a full-scale anaerobic digestion plant during different process phases: starting (nondigestion), digestion, and post-digestion. Biological stability parameters are determined by both aerobic (oxygen demand, $\mathrm{OD}_{20}$ ) and anaerobic (anaerobic biogasification potential, $\mathrm{ABP}$ ) measurements. In addition, odourous emissions were measured using three different methodologies: olfactometry, an electronic nose (EN), and gas chromatography mass spectrometry (GC-MS) (VOC determination) to get more in-depth information about the nature of odours compounds.

\section{Methods}

\subsection{Waste sample collection}

A full-scale anaerobic digestion plant located in Northern Italy was monitored during this study. In this plant, $1 \mathrm{MW}$ of electrical power is produced by digesting in four anaerobic continuously stirred thermophilic reactors (CSTR) and in an identical anaerobic post-digester (Pognani et al., 2009), the organic fraction of municipal solid waste (OFMSW). OFMSW came from door to door source separation collection. Waste was composed of $90 \%$ (on wet weight basis, w.w.b.) of kitchen wastes and of 5-10\% (w.w.b.) of plastic bags.

Anaerobic digestion operated under wet condition and the average total solid contents measured in the digester resulted of $4.65 \pm 0.88 \%$ w.w. (Table 1 ).

The plant treats around $30,000 \mathrm{Mg}$ of waste per year. The first stage of the treatment process consists of crushing and squeezing the organic wastes separating plastic bag from the waste. The resulting slurry is then fed to anaerobic digesters at a rate of $0.22 \mathrm{Mg}$ every $15 \mathrm{~min}$. The digesters work under thermophilic conditions (at $55^{\circ} \mathrm{C}$ ) with a hydraulic retention time (HRT) of 40 days, followed by post-digestion where the material remains for about 10 days.

During the monitoring period (September-December 2008), three sampling campaigns were undertaken (on 15/09/08, 07/10/ 08 and $11 / 11 / 08$, indicated as replicates 1,2 and 3 , respectively), each collecting samples from the feed-in (ingestates) (ND) (HRT $=0$ days), output from the thermophilic anaerobic reactors
(D) $(\mathrm{HRT}=40$ days), and output from the post-digester (PD) (HRT $=50$ days).

Non-digested (ND) and digested samples (D and PD) were directly taken from the roof of the mix tank and fermenters. For each sample composite slurry of about $5 \mathrm{l}$ was obtained by using a $500 \mathrm{ml}$ jar with telescopic bar, used as sampler. Composite samples were stored in a 51 glass container avoiding headspace presence. Samples were stored in glass containers hermetically closed avoiding any contact with air and any molecules volatilization. Then samples were brought to the laboratory and worked within $2 \mathrm{~h}$.

\subsection{Chemical characterization of waste samples}

Representative samples were used to carry out all the analytical tests. Total solids (TS), volatile solids (VS), and total organic carbon (TOC) were determined according to standard procedures (APHA, 1998). Ammonia and total N-Kjeldahl (TKN) were analysed on fresh samples according to the analytical method established for wastewater sludge (IRSA CNR, 1994). $\mathrm{pH}$ and volatile fatty acids (VFA) were determined according to standard procedures (US Department of Agriculture and US Composting Council, 2002). All analyses were performed in triplicate.

\subsection{Anaerobic biogasification potential ( $A B P)$}

The estimation of $A B P$ was performed according to Schievano et al. (2008) using $0.62 \mathrm{~g}$ of dried matter sample, $37.5 \mathrm{ml}$ of inocu$\mathrm{lum}$, and $22 \mathrm{ml}$ of deionized water in 100-ml serum bottles. A control blank was prepared with $60 \mathrm{ml}$ of inoculum. The biogas production was determined and expressed as $\mathrm{Nl} \mathrm{kg}^{-1}$ TS. All batches were sealed with Teflon hermetic caps, flushed with an $\mathrm{N}_{2}$ atmosphere, and incubated at $37 \pm 1^{\circ} \mathrm{C}$, until no further biogas production was detected (normally around 60 days). Assay bottles were periodically analysed for both quantitative and qualitative determination of biogas production. Quantitative biogas production was estimated by withdrawing extra-pressure gas with a 60$\mathrm{ml}$ syringe. Biogas production of blank control batches was subtracted from biogas production of every sample. Qualitative characterization of biogas was performed by a gas chromatograph (Carlo Erba Megaseries 5300, capillary column $25 \mathrm{~m} \times 0.32 \mathrm{~mm}$ diameter and flame ionization detector [FID]) to determine $\mathrm{CH}_{4}: \mathrm{CO}_{2}$ ratio in the biogas. The carrier gas was nitrogen at $20 \mathrm{kPa}$ pressure and temperatures of injector and FID were 130 and $150^{\circ} \mathrm{C}$, respectively. Comparison of obtained peak areas was carried out with a standard gas mixture of $300: 700 \mathrm{ml} \mathrm{l}^{-1}(\mathrm{v} / \mathrm{v})$ $\mathrm{CH}_{4}: \mathrm{CO}_{2}$. All the tests were performed in triplicate.

\subsection{Oxygen demand $\left(\mathrm{OD}_{20}\right)$}

Oxygen demand test was performed in relation to the method described in Lasaridi and Stentiford (1998), and modified by Adani et al. (2003). To perform the test, $0.4 \mathrm{~g}$ of dried matter sample were set in a flask with $500 \mathrm{ml}$ of deionized water, $12 \mathrm{ml}$ of phosphate buffer solution $\left(\mathrm{KH}_{2} \mathrm{PO}_{4}, \mathrm{~K}_{2} \mathrm{HPO}_{4}, \mathrm{Na}_{2} \mathrm{HPO}_{4} \cdots 7 \mathrm{H}_{2} \mathrm{O}\right)$, and $5 \mathrm{ml}$ of nutritive solution $\left(\mathrm{CaCl}_{2}, \mathrm{FeCl}_{3}\right.$, and $\left.\mathrm{MgSO}_{4}\right)$ prepared according to the standard BOD test procedures (APHA, 1998). The oxygen uptake potential is the result of the oxygen demand accrued in a 20-h test $\left(\mathrm{OD}_{20}, \mathrm{mg} \mathrm{O}_{2} \mathrm{~g} \mathrm{TS}^{-1}\right)$, calculated using the following equation:

$$
\mathrm{OD}_{20}=\frac{V}{m * \mathrm{TS} * 100} * \int_{t=0}^{t=20}|S|_{t} * \mathrm{~d} t
$$

where $m$ is the mass of the sample (g, wet weight), $V$ the sample volume, TS the total solid content of the sample in \% over wet weight, and $|S|_{t}$ the rate of oxygen consumption at time $t\left(\mathrm{mg} \mathrm{O}_{2}\right.$ $\mathrm{L}^{-1} \mathrm{~h}^{-1}$ ). All the tests were performed in triplicate. 
Table 1

Chemical characteristics of the samples analysed (ND: non-digested, D: digested and PD: post-digested).

\begin{tabular}{|c|c|c|c|c|c|c|c|c|c|}
\hline Sample & Sampling data & Process time (days) & $\mathrm{pH}$ & TS (\%WW) & VS (\%TS) & TOC (\%TS) & TKN (\%TS) & $\mathrm{NH}_{3}\left(\mathrm{mg} \mathrm{l}^{-1}\right)$ & VFA $\left(\mathrm{mg} \mathrm{l}^{-1}\right)$ \\
\hline ND1 & $15 / 09 / 08$ & 0 & 4.41 & $15.25^{\mathrm{a}} \pm 0.35^{\mathrm{b}}$ & $87.49 \pm 0.13$ & $45.02 \pm 0.84$ & $3.26 \pm 0.30$ & $1038 \pm 112$ & $21,566 \pm 708$ \\
\hline ND2 & $07 / 10 / 08$ & 0 & 4.56 & $22.05 \pm 0.02$ & $89.90 \pm 0.14$ & $46.56 \pm 0.37$ & $2.61 \pm 0.16$ & $1227 \pm 21$ & $26,188 \pm 9330$ \\
\hline ND3 & $11 / 11 / 08$ & 0 & 3.84 & $14.29 \pm 0.13$ & $86.16 \pm 0.20$ & $49.11 \pm 0.89$ & $3.40 \pm 0.05$ & $834 \pm 38$ & $27,220 \pm 1881$ \\
\hline Mean ND & & & & $17.20 \pm 3.81^{b c}$ & $87.85 \pm 1.69^{b}$ & $46.90 \pm 1.93^{\mathrm{b}}$ & $3.09 \pm 0.41^{a}$ & $1033 \pm 183^{a}$ & $24,135 \pm 3024^{b}$ \\
\hline D1 & $15 / 09 / 08$ & 40 & 8.20 & $3.83 \pm 0.19$ & $67.61 \pm 1.00$ & $39.25 \pm 1.09$ & $13.35 \pm 0.15$ & $3458 \pm 473$ & $7539 \pm 148$ \\
\hline D2 & $07 / 10 / 08$ & 40 & 8.22 & $4.42 \pm 0.39$ & $67.11 \pm 1.00$ & $37.09 \pm 0.84$ & $10.90 \pm 0.09$ & $2913 \pm 64$ & $6579 \pm 598$ \\
\hline D3 & $11 / 11 / 08$ & 40 & 8.13 & $5.69 \pm 0.29$ & $72.02 \pm 0.01$ & $42.34 \pm 0.71$ & $9.00 \pm 0.08$ & $3139 \pm 48$ & $10,180 \pm 573$ \\
\hline Mean D & & & & $4.65 \pm 0.88^{\mathrm{a}}$ & $68.91 \pm 4.05^{a}$ & $39.56 \pm 2.46^{a}$ & $11.08 \pm 1.95^{\mathrm{b}}$ & $3170 \pm 325^{b}$ & $8100 \pm 1709^{a}$ \\
\hline PD1 & $15 / 09 / 08$ & 50 & 8.35 & $3.77 \pm 0.42$ & $64.84 \pm 0.13$ & $36.23 \pm 0.88$ & $13.07 \pm 0.32$ & $3622 \pm 38$ & $1021 \pm 322$ \\
\hline PD2 & $07 / 10 / 08$ & 50 & 8.28 & $6.49 \pm 0.58$ & $58.06 \pm 0.49$ & $35.24 \pm 0.89$ & $6.45 \pm 0.57$ & $3128 \pm 3$ & $1839 \pm 166$ \\
\hline PD3 & $11 / 11 / 08$ & 50 & 8.20 & $4.30 \pm 0.01$ & $64.45 \pm 0.11$ & $38.35 \pm 1.20$ & $11.83 \pm 0.06$ & $3266 \pm 9$ & $9498 \pm 779$ \\
\hline Mean PD & & & & $4.85 \pm 0.60^{\mathrm{a}}$ & $62.45 \pm 3.41^{\mathrm{a}}$ & $36.61 \pm 1.61^{\mathrm{a}}$ & $10.45 \pm 3.16^{b}$ & $3339 \pm 229^{b}$ & $4832 \pm 4519^{a}$ \\
\hline
\end{tabular}

a All data reported in Table 1, except $\mathrm{pH}$, are average of three replicates.

b The value after symbol $( \pm)$ is the standard deviation.

c Value in the same column followed by the same letter are not statistically different (Tukey test, $P<0.05$ ).

\subsection{Odour sample collection}

From each waste sample the gaseous samples for odour detection were collected using a flux chamber system based on the APAT method (APAT, 2003) (Fig. S1) (see Supplementary material). In brief, four litres of waste sample were put in a tray container and covered with a Plexiglas chamber $(38.8 \times 50.5 \times 40 \mathrm{~cm})$ having a surface of $0.196 \mathrm{~m}^{2}$. The chamber was then continuously flushed for $10 \mathrm{~min}$ with air (airflow rate of $0.35 \mathrm{~m}^{3} \mathrm{~h}^{-1}$ ). Output gas from the chamber was then taken from the outlet port and stored in Nalophan bags. Bags of different volumes, i.e., 20 1, 2 1, and 3 1, were filled and used for olfactometric, electronic nose, and GC-MS analyses, respectively.

\subsection{Olfactometry}

Olfactometric analyses were carried out in conformity with the standardized EN method n. 13725 (CEN, 2003). An Olfaktomat-N 6 (six stations) olfactometer (PRA-Odournet B.V., Amsterdam, NL) based on the forced choice method was used as a dilution device. Six panellists were employed during test.

The measuring range of the olfactometer starts from a maximum dilution factor of 33,000 with a dilution step factor of 2 . The results of the olfactometry were expressed as odour concentration value $\left(\mathrm{OU}_{\mathrm{E}} \mathrm{Nm}^{-3}\right)$. On the other hand, the odour emission rate $(\mathrm{OE})$ was calculated by using the following equation:

$\mathrm{OE}=\mathrm{CQ} / \mathrm{S}$

in which $\mathrm{OE}$ is the odour emission rate $\left(\mathrm{OU}_{\mathrm{E}} \mathrm{Nm}^{-2} \mathrm{~h}^{-1}\right), C$ is the odour concentration $\left(\mathrm{OU}_{\mathrm{E}} \mathrm{Nm}^{-3}\right), Q$ is the incoming air rate to the flux chamber $\left(0.35 \mathrm{~m}^{3} \mathrm{~h}^{-1}\right)$, and $S$ the surface covered by the chamber $\left(0.196 \mathrm{~m}^{2}\right)$.

\subsection{Electronic nose}

Air samples were analysed using a PEN2 electronic nose (Airsense Analytics, Schwerin, Germany) equipped with 10 thermoregulated $\left(150-500{ }^{\circ} \mathrm{C}\right)$ sensors $(\mathrm{S} 1-\mathrm{S} 10)$ made of metal oxide semiconductors (MOS). Each sensor is sensitive to a group of class compounds; i.e., S1: aromatic compounds; S2: polar compounds and nitrogen oxides; S3: aromatic compounds, ketones, and aldehydes; $\mathrm{S} 4: \mathrm{H}_{2}$; S5: low polarity aromatic and alkane compounds; S6: methane compounds; S7: sulphur compounds and terpenes; S8: alcohols, ketones, and partially aromatic compounds; S9: sulphur-containing and aromatic compounds; and S10: methane at high concentration. The measurement modalities adopted were as reported by D'Imporzano et al. (2008), except that the Nalophan bags were connected directly to the EN through a probe. The following work parameters were used: (i) $300 \mathrm{~s}$ for the clean cycle, (ii) $100 \mathrm{~s}$ for the measurement cycle, and (iii) three cycles for each bag. Only the last $20 \mathrm{~s}$ of the measurement cycles, when the response of the sensors was stabilized, were chosen to create the sensor patterns. A total of 21 measures were obtained for each cycle.

The large amount of data obtained by the EN required the information obtained to be reduced to a limited number of new variables able to describe the totality of the variability (generally two-dimensional variables).

As a consequence, the odour results were elaborated by multivariate analysis. In this work, principal component analysis (PCA) was used to compare odours qualitatively. The multivariate analyses were carried out by an ad hoc software (SCAN, Minitab Inc., State College, PA).

\subsection{Gas chromatography-mass spectrometry}

Volatile organic compounds (VOC) from air samples were analysed by SPME/GC-MS (Davoli et al., 2003). A manual SPME device and divinylbenzene (DVB)/Carboxen/polydimethylsiloxane (PDMS 50-30 $\mu \mathrm{m}$ fiber - Supelco, Bellefonte, PA, USA) were used. The analytes were adsorbed from the air samples by exposing the fiber, preconditioned for $3 \mathrm{~h}$ at $250^{\circ} \mathrm{C}$ as suggested by the supplier, in Nalophan bags for $30 \mathrm{~min}$ at room temperature. A solution of perdeuterated p-xylene in methanol was used as internal standard (IS) for quantitative analysis. VOC analysis was performed using an Agilent 5975C Series GC/MSD. Volatiles were separated using a capillary column for VOC (Meta.VOC, Teknokroma, Sant Cugat del Vallès, Barcelona, Spain) $30 \mathrm{~m} \times 0.32 \mathrm{~mm}$ ID, with a film thickness of $3.0 \mu \mathrm{m}$. The carrier gas was helium at a flow rate of $1 \mathrm{ml} \mathrm{min}{ }^{-1}$. VOCs were desorbed, exposing the fiber in the GC injection port for $3 \mathrm{~min}$ at $250^{\circ} \mathrm{C}$. A $2 \mathrm{~mm}$ glass liner was used, and the injection port was in splitless mode. The temperature program was isothermal for $3 \mathrm{~min}$ at $35^{\circ} \mathrm{C}$, raised to $200{ }^{\circ} \mathrm{C}$ at a rate of $8{ }^{\circ} \mathrm{C} / \mathrm{min}$. The transfer line to the mass spectrometer was maintained at $250^{\circ} \mathrm{C}$. The mass spectra were obtained by electronic impact at $70 \mathrm{eV}$, with a multiplier voltage of $1294 \mathrm{~V}$ and collecting data at a $\mathrm{m} / \mathrm{z}$ range of 33-300. Compounds were tentatively identified by comparing their mass spectra with those contained in the NIST (USA) 98 library. Semi-quantitative analysis for all the identified compounds was performed by direct comparison with the internal standard. Results were expressed as part per billion on a volume basis (ppbv).

GC-MS data were reduced in chemical classes that were then used for the successive principal component analysis (PCA) (Davoli 
et al., 2003) using an ad hoc software (SCAN, Minitab Inc., State College, PA).

\subsection{Statistical analyses}

All statistical analyses otherwise reported in each specific paragraph were performed with the SPSS statistical software (version 13) (SPSS, Chicago, IL).

Partial least squares (PLS) analysis (Einax et al., 1997) was used for modeling the relationship of odours (OU as $\mathrm{OU}_{\mathrm{E}} \mathrm{Nm}^{-2} \mathrm{~h}^{-1}$ ) with the EN data (dimensionless arbitrary unit) and GC-MS data (molecular classes expressed as ppbv), and with respirometric data $\left(\mathrm{OD}_{20}\right.$ expressed as $\left.\mathrm{mg} \mathrm{O} \mathrm{O}_{2} \mathrm{~g} \mathrm{TS}^{-1}\right)$ using an ad hoc software (SCAN, Minitab Inc., State College, PA). Both the goodness of fit, i.e., regression coefficient $\left(R^{2}\right)$, and the goodness of prediction, i.e., cross-validation regression coefficients $\left(R_{\mathrm{cv}}^{2}\right)\left(R^{2}\right.$ obtained using values calculated by using the regression model) were reported. The cross-validation regression coefficient was calculated as an error of the prediction by the leave-one-out cross-validation procedure. This procedure allows the selection of more appropriate latent vectors, thus reducing their total number (i.e., the selection of the EN sensor and organic compound classes able to predict olfactometric units).

For the GC-MS data, organic compound classes were used for PLS application, taking into consideration those classes that were effectively represented; i.e., esters, aromatics, alcohols, carbonyl, and terpenes (see subsequent text).

\section{Results and discussion}

The chemical characteristics of the analysed samples are shown in Table 1. There was a clear difference in the TS, VS, and TOC contents of non-digested and digested materials as a consequence of OM degradation. However, this difference did not exist for samples corresponding to digested and post-digested wastes. Regarding the VFA content, the higher values in the starting samples (ND) were ascribed to the hydrolysis and successive fermentation of organic matter that occurred during waste transportation and storage. During anaerobic digestion and post-digestion, VFA were transformed to $\mathrm{CH}_{4}$ and $\mathrm{CO}_{2}$, resulting in digested (D) and post-digested (PD) samples with lower VFA concentration. Total nitrogen (TKN) content was lower in ND samples than in both $\mathrm{D}$ and PD materials because of nitrogen concentration as a consequence of volatile solid degradation. Ammonia concentration $\left(\mathrm{NH}_{3}\right)$ increased, as well, during the process due to the mineralization of the organic $\mathrm{N}$.
The biological stability of the materials (Table 2), measured as $\mathrm{OD}_{20}$ and $\mathrm{ABP}$, increased throughout the treatment process as a consequence of the degradation of organic matter (Schievano et al., 2008; Pognani et al., 2009). This was confirmed by the good linear and positive correlations (Pearson correlation) obtained by processing the mean values of biological stability parameters vs VS and TOC (Tables 1 and 2, i.e., $\mathrm{OD}_{20}$ and ABP vs VS and TOC $\left(\mathrm{OD}_{20}\right.$ vs VS: $r=0.92, P<0.05 ; n=9 \mathrm{OD}_{20}$ vs TOC content: $r=0.91, P<0.05 ; n=9$; ABP vs VS: $r=0.88, P<0.05 ; n=9$; ABP vs TOC content: $r=0.86, P<0.05 ; n=9$ ). The fact that correlation coefficients were higher for $\mathrm{OD}_{20}$ than $\mathrm{ABP}$ could indicate that biological stability was affected, mostly by the degradation of the more readily degradable organic matter. This is confirmed by the good correlation obtained for $\mathrm{OD}_{20}$ and VFA content $\left(\mathrm{OD}_{20}\right.$ vs VFA content: $r=0.93, P<0.05 ; n=9$ ), with $\mathrm{OD}_{20}$ being more greatly affected than $A B P$ by the easily degradable organic matter (Schievano et al., 2008).

As the biological stability increased, odour emissions reduced (reported as odour unit per square meter per hour: $\mathrm{OU}_{\mathrm{E}}$ $\mathrm{Nm}^{-2} \mathrm{~h}^{-1}$ ) (Table 2), although no correlation was found between these parameters, and no statistical significance was observed between average values reported in Table 2 . This was due to the high variability of the emitted odours measured in the starting sample, which reflected the variability of the feeding waste that generally occurs in a full-scale plant (Pognani et al., 2009). In particular, when starting sample was characterized by low odour emissions (see Sample ND3) (Table 2) only a slight odour reduction occurred during the process. Nevertheless, when odour impact of the starting sample was high (see Samples ND1 and ND2) (Table 2), a strong reduction occurred in the digested samples.

The tendency of odour increment in the final sample (PD) with respect to the digested sample (D) (Table 2 ), could be ascribed to the lower microbiological activity (see ABP data) for PD with respect sample $\mathrm{D}$, that limited odour stripping from the biomass via biogas production, thus resulting in odour concentration in the waste. Nevertheless, differences observed were not statistically different.

Odours are due to the presence of volatile organic compounds in the air. Nevertheless, direct quantification of the VOCs did not allow determination of the odour impact (odour units), and no relationship was found between these two parameters (Table 2). Moreover, the VOC contents appeared very similar, on the average, for all samples considered, although a reduction during the process was observed (Table 2).

Dynamic olfactometry and VOC measurement both represented quantitative measurements of the molecules present in air

Table 2

Biological stability indices and odours emission characteristic of the samples analysed (ND: non-digested, D: digested and PD: post-digested).

\begin{tabular}{|c|c|c|c|c|c|c|c|}
\hline Sample & Sampling data & Process time (days) & $\mathrm{OD}_{20}\left(\mathrm{mg} \mathrm{O}_{2} \mathrm{~g}^{-1} \mathrm{TS}\right)$ & $\mathrm{ABP}\left(\mathrm{Nl} \mathrm{kg}{ }^{-1} \mathrm{TS}\right)$ & Odour $\left(\mathrm{OU}_{\mathrm{E}} \mathrm{Nm}^{-2} \mathrm{~h}^{-1}\right)$ & VOC (ppbv) & $\mathrm{NH}_{3}$ (ppmv) \\
\hline ND1 & $15 / 09 / 08$ & 0 & $279.70^{\mathrm{a}} \pm 21.50^{\mathrm{b}}$ & $546.89^{\mathrm{a}} \pm 2.42$ & $119,446^{c}$ & $2,328^{c}$ & $0^{c}$ \\
\hline ND2 & $07 / 10 / 08$ & 0 & $218.50 \pm 18.67$ & $483.12 \pm 8.71$ & 76,017 & 1672 & 15 \\
\hline ND3 & $11 / 11 / 08$ & 0 & $293.79 \pm 0.18$ & $481.60 \pm 1.36$ & 36,243 & 6005 & 5 \\
\hline Mean ND & & & $264.00 \pm 40.03^{\mathrm{bd}}$ & $503.87 \pm 33.60^{\mathrm{b}}$ & $77,235 \pm 41,614^{\mathrm{a}}$ & $3335 \pm 2335^{a}$ & $6.67 \pm 7.64^{\mathrm{a}}$ \\
\hline D1 & $15 / 09 / 08$ & 40 & $116.28 \pm 19.55$ & $217.16 \pm 0.84$ & 5458 & 1208 & 104 \\
\hline D2 & $07 / 10 / 08$ & 40 & $152.99 \pm 11.21$ & $338.00 \pm 3.06$ & 17,550 & 1178 & 54 \\
\hline D3 & $11 / 11 / 08$ & 40 & $136.46 \pm 0.87$ & $441.05 \pm 0.41$ & 29,331 & 1694 & 45 \\
\hline Mean D & & & $135.24 \pm 18.40^{\mathrm{a}}$ & $332.07 \pm 100.24^{\mathrm{ab}}$ & $17,446 \pm 11,936^{\mathrm{a}}$ & $1360 \pm 290^{\mathrm{a}}$ & $67.67 \pm 31.79^{b}$ \\
\hline PD1 & $15 / 09 / 08$ & 50 & $88.93 \pm 3.31$ & $101.49 \pm 10.1$ & 13,314 & 1303 & 30 \\
\hline PD2 & $07 / 10 / 08$ & 50 & $83.13 \pm 3.84$ & $192.87 \pm 2.54$ & 40,213 & 1180 & 45 \\
\hline PD3 & $11 / 11 / 08$ & 50 & $112.89 \pm 12.36$ & $178.75 \pm 0.38$ & 23,087 & 2784 & 57 \\
\hline Mean PD & & & $94.98 \pm 15.80^{\mathrm{a}}$ & $157.70 \pm 44.25^{\mathrm{a}}$ & $25,538 \pm 13,615^{a}$ & $1756 \pm 893^{a}$ & $44 \pm 13.53^{\mathrm{ab}}$ \\
\hline
\end{tabular}

\footnotetext{
${ }^{a}$ The data are average of three replicates.

b The data are a single replicate.

c The value after symbol ( \pm ) is the standard deviation.

d Value in the same column followed by the same letter are not statistically different (Tukey test, $P<0.05$ ).
} 
samples, but they were not able to identify the kind of molecules present in the air that were responsible for the odours.

The electronic nose has been used in the past to give a rapid characterization of the organic molecules composing the air and to follow the changes in emitted volatile compounds during the fermentation process (Eklöv et al., 1998). In this work it was used to track the odour fingerprint of both ingestate and digestate. The EN patterns for the samples analysed, presented in Fig. 1, showed a decrease in the EN sensor responses with the process time and with the acquirement of biological stability.
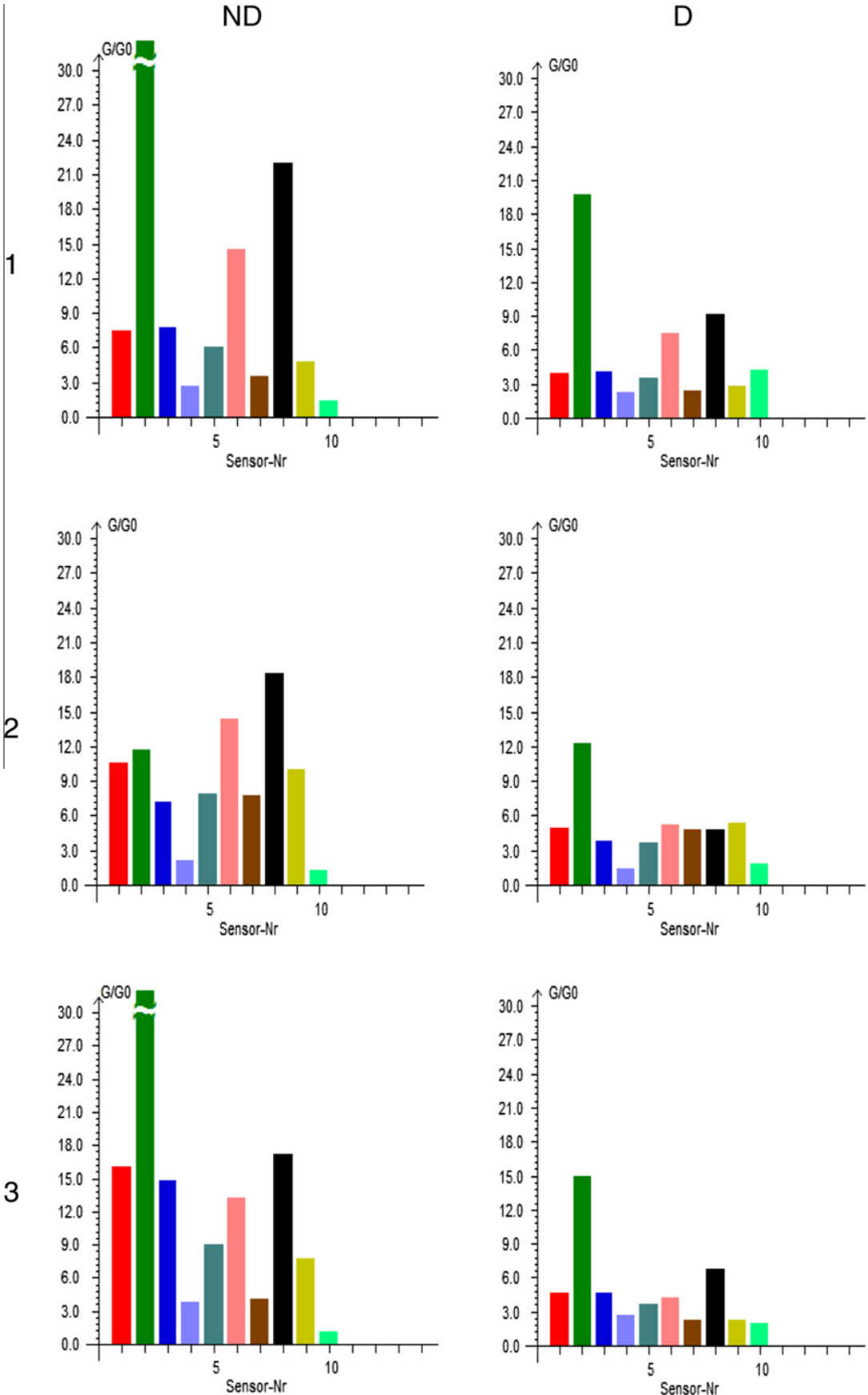

Sensor S1

Sensor S2

Sensor S3

Sensor S4

Sensor S6

Sensor S7

Sensor S8

Sensor S9
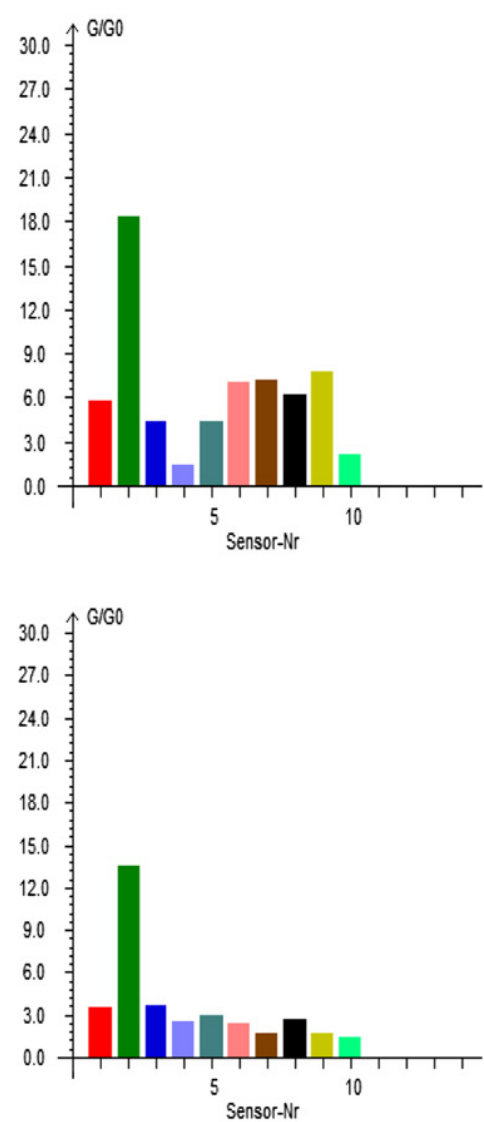

Sensor S5

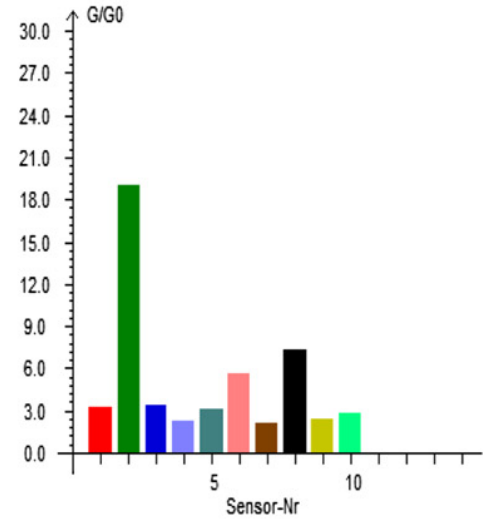

Sensor S10

Fig. 1. EN signal registered in samples of indigestate (ND), digestate (D), and post-digestate (PD) coming from the three sampling campaigns (Sampling data, $1: 15 / 09 / 08,2$ : $07 / 10 / 08$ and $3: 11 / 11 / 08)$. ( $x$-axis represents sensor number and $y$-axis relative sensor signal). 
explained). PC1 and PC2, which together accounted for $87 \%$ of the total variance, indicated that the odour fingerprints were similar when the biological stabilities of the samples were similar. This was confirmed by the good regression found in the PLS analysis of $\mathrm{OD}_{20}$ vs the $\mathrm{EN}\left(R^{2}=0.99 ; R_{\mathrm{cv}}^{2}=0.98, P<0.01\right.$, sensors selected: S1-S7).

From these data, it can be concluded that the odour reduction due to the acquirement of biological stability was accompanied by a change in the organic molecules composing the air in the wastes studied.

This fact is confirmed by the data in Fig. 3, which shows the VOC fingerprints analysed by GC-MS as compound classes (Table 3 ) and elaborated on a bi-dimensional PCA plot; i.e., samples having similar biological stability showed similar VOC patterns. Again, good regression was found in the PLS analysis of $\mathrm{OD}_{20}$ vs the GC-MS data $\left(R^{2}=0.95 ; R_{\mathrm{cv}}^{2}=0.78, P<0.01\right.$, organic compounds selected: ester, aromatics, and alcohols). The statistical data showed that the
GC-MS data were less predictive than the EN data in describing $\mathrm{OD}_{20}$.

To get more in-depth knowledge of the organic molecules comprising waste-air, single molecules were elaborated from the GCMS spectra and quantified.

The VOCs present in the air of the ingestate consisted mostly (average of 3 measures) of terpenes (61\%), alcohols (18\%), and esters $(9 \%)$ (Table 3$)$. The changes that occurred during anaerobic digestion led to digested samples characterized by still-high presence of terpenes ( $51 \%$ and $58 \%$ for D and PD samples, respectively), strong reduction of both alcohols and esters, and high presence of carbonyl compounds (40\% and $34 \%$ for D and PD samples, respectively).

Fresh wastes (ND) were particularly characterized by the presence of the terpenes, limonene (Table 4) and beta-pinene, both widespread in fruits, vegetables, and pine species (Staley et al., 2006), and thus compose the VOCs of the OFMSW (Smet et al.,

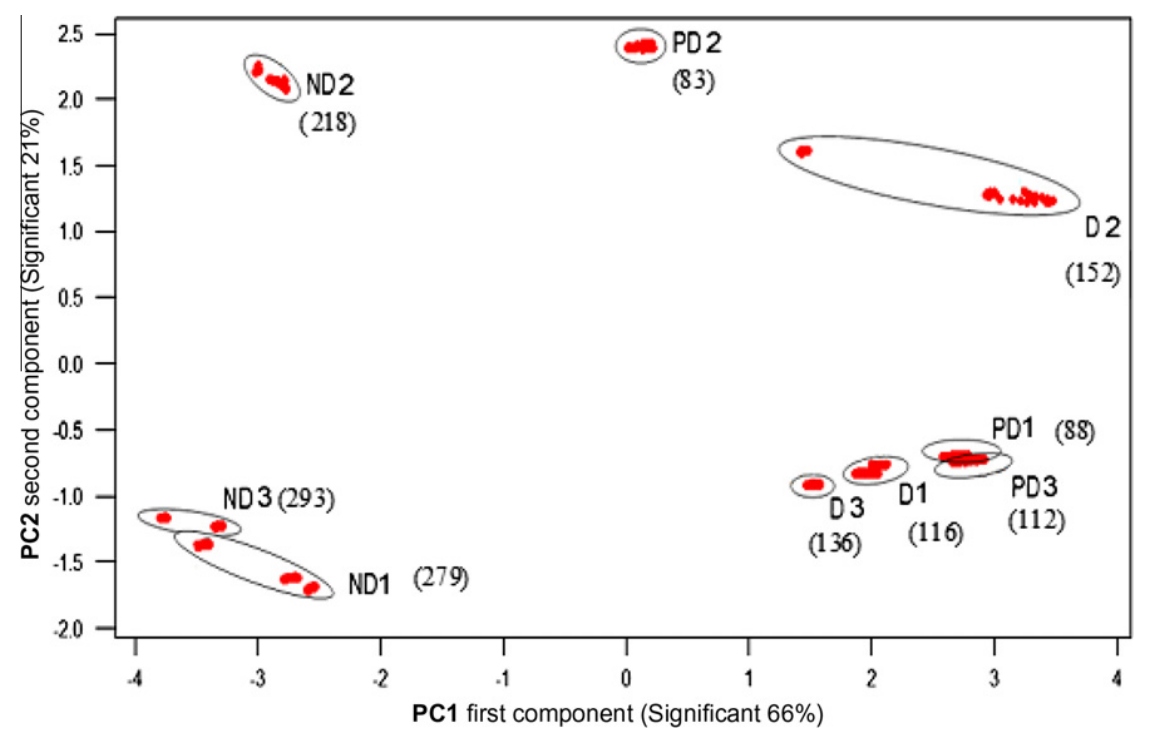

Fig. 2. PCA plot of odours measured by Electronic nose $\left(x\right.$, in parenthesis are reported respirometric data (OD20 as mg $\left.\mathrm{O}_{2} \mathrm{~g}^{-1} \mathrm{TS}\right)(\mathrm{Sampling}$ data, $1: 15 / 09 / 08,2: 07 / 10 / 08$ and 3: $11 / 11 / 08)$.

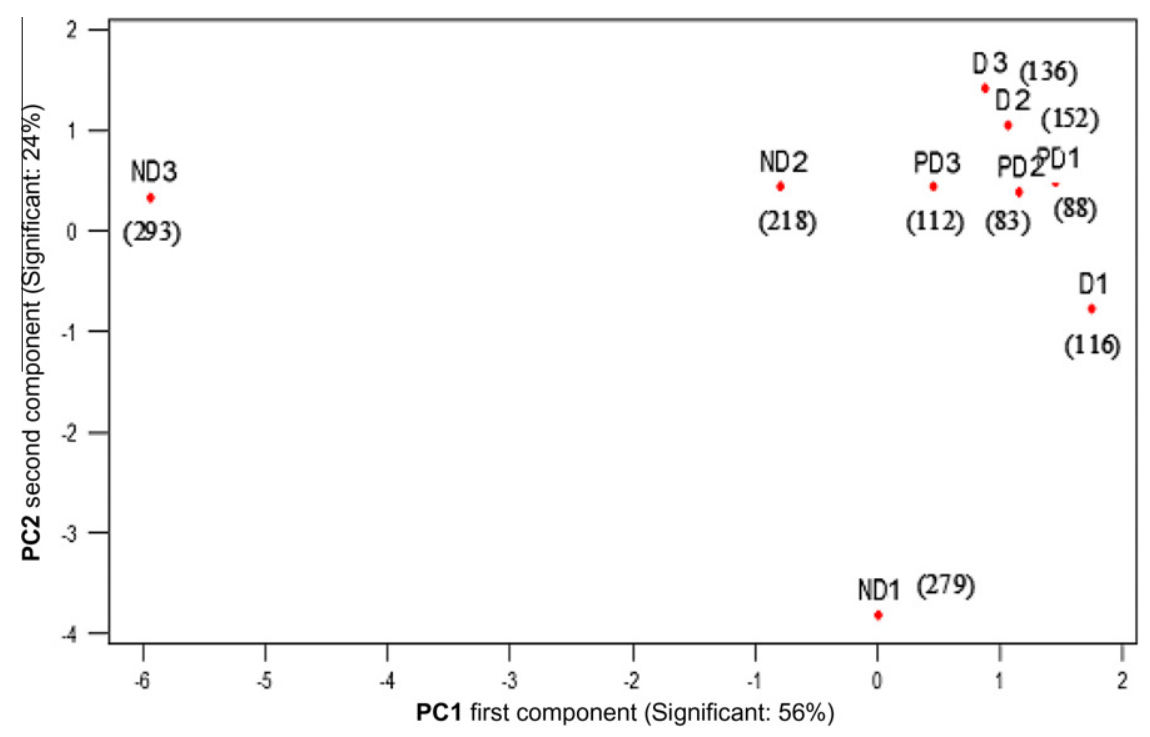

Fig. 3. PCA plot of total VOCs measured by GC-MS analysis (organic compounds classes from Table 3 ) in parenthesis are reported respirometric data (OD20 as mg $\mathrm{O}_{2} \mathrm{~g}^{-1}$ TS) (Sampling data, 1: 15/09/08, 2: 07/10/08 and 3: 11/11/08). 
Table 3

Volatile organic compounds (VOCs) emitted (ppbv) from samples studied: non-digested (ND, 0 days of process); digested (D, after 40 days of process) and post-digested (PD, after 50 days of process) wastes. The mean percentage of each type of VOCs over the total VOCs emission is also presented.

\begin{tabular}{|c|c|c|c|c|c|c|c|c|c|c|c|c|}
\hline \multirow[b]{2}{*}{$\begin{array}{l}\text { Sample (sampling } \\
\text { data) } \\
\text { Organic compound } \\
\text { classes }\end{array}$} & \multicolumn{4}{|l|}{ ND } & \multicolumn{4}{|l|}{$\mathrm{D}$} & \multicolumn{4}{|l|}{$\mathrm{PD}$} \\
\hline & $\begin{array}{l}1 \\
(15 / 09 / 08) \\
\text { ppbv }\end{array}$ & $\begin{array}{l}2 \\
(07 / 10 / 08) \\
\text { ppbv }\end{array}$ & $\begin{array}{l}3 \\
(11 / 11 / 08) \\
\text { ppbv }\end{array}$ & Mean \% & $\begin{array}{l}1 \\
(15 / 09 / 08) \\
\text { ppbv }\end{array}$ & $\begin{array}{l}2 \\
(07 / 10 / 08) \\
\text { ppbv }\end{array}$ & $\begin{array}{l}3 \\
(11 / 11 / 08) \\
\text { ppbv }\end{array}$ & Mean \% & $\begin{array}{l}1 \\
(15 / 09 / 08) \\
\text { ppbv }\end{array}$ & $\begin{array}{l}2 \\
(07 / 10 / 08) \\
\text { ppbv }\end{array}$ & $\begin{array}{l}3 \\
(11 / 11 / 08) \\
\text { ppbv }\end{array}$ & Mean \% \\
\hline Nitrogen compounds & 0.00 & 0.00 & 3.42 & 0.03 & 0.00 & 7.11 & 0.66 & 0.19 & 0.00 & 3.19 & 0.00 & 0.06 \\
\hline Esters & 224.31 & 310.29 & 355.26 & 8.89 & 0.00 & 12.73 & 1.66 & 0.35 & 39.55 & 6.90 & 60.12 & 2.02 \\
\hline Aliphatic hydrocarbons & 2.07 & 30.23 & 20.43 & 0.53 & 0.48 & 13.65 & 14.02 & 0.69 & 14.42 & 9.44 & 22.55 & 0.88 \\
\hline Aromatic hydrocarbons & 19.27 & 39.07 & 28.49 & 0.87 & 22.28 & 40.03 & 55.05 & 2.88 & 41.77 & 29.68 & 20.93 & 1.75 \\
\hline Alcohols & 762.00 & 412.93 & 585.00 & 17.59 & 81.89 & 82.64 & 38.50 & 4.98 & 76.26 & 35.40 & 0.00 & 2.12 \\
\hline Ethers & 78.70 & 0.17 & 0.00 & 0.79 & 4.19 & 6.36 & 1.72 & 0.30 & 1.30 & 1.72 & 4.26 & 0.14 \\
\hline Carbonyl compounds & 558.04 & 171.38 & 19.03 & 7.48 & 685.38 & 515.01 & 423.63 & 39.80 & 680.96 & 463.60 & 671.64 & 34.47 \\
\hline Terpens & 683.47 & 708.29 & 4749.90 & 61.38 & 413.91 & 500.50 & 1150.79 & 50.61 & 449.33 & 630.18 & 1999.43 & 58.44 \\
\hline Sulphur compounds & 0.00 & 0.00 & 79.60 & 0.79 & 0.00 & 0.00 & 8.08 & 0.20 & 0.00 & 0.00 & 4.80 & 0.09 \\
\hline Halogenates & 0.08 & 0.00 & 0.00 & 0.00 & 0.00 & 0.00 & 0.33 & 0.01 & 0.00 & 0.00 & 1.05 & 0.02 \\
\hline Acids & 0.00 & 0.00 & 164.75 & 1.65 & 0.00 & 0.00 & 0.00 & 0.00 & 0.00 & 0.00 & 0.00 & 0.00 \\
\hline Total VOCs & 2327.94 & 1672.35 & 6005.87 & 100 & 1208.12 & 1178.03 & 1694.44 & 100 & 1303.60 & 1180.12 & 2784.77 & 100 \\
\hline
\end{tabular}

Table 4

Main compounds found in the air samples analysed: non-digested (ND, 0 days of process); digested (D, after 40 days of process) and post-digested (PD, after 50 days of process) wastes.

\begin{tabular}{|c|c|c|c|c|c|c|c|c|c|}
\hline \multirow{2}{*}{$\begin{array}{l}\text { Sample (sampling data) } \\
\text { Organic compounds }\end{array}$} & \multicolumn{3}{|l|}{ ND } & \multicolumn{3}{|l|}{$\mathrm{D}$} & \multicolumn{3}{|l|}{ PD } \\
\hline & $\begin{array}{l}1(15 / 09 / 08) \\
\text { ppbv }\end{array}$ & $\begin{array}{l}2(07 / 10 / 08) \\
\text { ppbv }\end{array}$ & $\begin{array}{l}3(11 / 11 / 08) \\
\text { ppbv }\end{array}$ & $\begin{array}{l}1(15 / 09 / 08) \\
\text { ppbv }\end{array}$ & $\begin{array}{l}2(07 / 10 / 08) \\
\text { ppbv }\end{array}$ & $\begin{array}{l}3(11 / 11 / 08) \\
\text { ppbv }\end{array}$ & $\begin{array}{l}1(15 / 09 / 08) \\
\text { ppbv }\end{array}$ & $\begin{array}{l}2(07 / 10 / 08) \\
\text { ppbv }\end{array}$ & $\begin{array}{l}3(11 / 11 / 08) \\
\text { ppbv }\end{array}$ \\
\hline Ethanol & 281 & 176 & 365 & - & 7 & 4 & - & - & - \\
\hline 2-Butanol & 208 & 105 & 131 & 75 & 63 & 17 & 57 & 24 & 12 \\
\hline 1-Propanol & 121 & 79 & 36 & - & - & - & - & - & - \\
\hline Ethyl acetate & 55 & 130 & 158 & - & - & - & - & - & - \\
\hline d-Limonene & 450 & 433 & 4389 & 178 & 323 & 920 & 10 & 26 & 778 \\
\hline p-Cymene & 80 & 64 & - & 134 & 53 & 59 & 352 & 501 & 1083 \\
\hline Beta-pinene & 78 & 80 & 26 & - & - & - & - & - & - \\
\hline Camphor & - & - & - & - & 28 & 21 & 29 & 37 & 40 \\
\hline Acetic acid & 86 & 43 & - & - & - & - & - & - & - \\
\hline Propanoic acid & 4 & 85 & - & - & - & - & - & - & - \\
\hline 2-Butanone & 337 & 32 & 12 & 556 & 416 & 311 & 589 & 337 & 558 \\
\hline 2 and 3-Pentanone & - & - & - & 15 & 18 & 12 & 20 & 16 & 12 \\
\hline 2-Heptanone & - & - & - & 24 & 24 & 43 & 24 & 32 & 35 \\
\hline
\end{tabular}

1999). Terpenes have been reported to be stripped during the first stage of aerobic biological processes, thus decreasing its concentration (Pierucci et al., 2005). Since anaerobic conditions are far different from the aerobic setting as no forced aeration is considered, terpenes were more or less conserved, thus also indicating that no significant degradation occurred, except in the sample 3 (Table 3 ). On the other hand, digested samples showed a high presence of p-cymene (Table 4), probably coming from the microbial transformation of d-limonene (Termonia and Termonia, 1999). p-Cymene has been reported to be a marker of the presence of old refuse kept under anaerobic conditions resulting in biogas production (Davoli et al., 2003).

The high presence of alcohols (ethanol, butanol, and propanol) (Table 4) in the air of fresh material was the consequence of microbial alcohol formation from waste substrate during the period of storage under nearly anaerobic conditions at low $\mathrm{pH}$ (Staley et al., 2006).

In the successive stable methanogenic phase, bacteria were able to oxidize the alcohols to ketone via the reduction of $\mathrm{CO}_{2}$ to $\mathrm{CH}_{4}$ (Widdel, 1986). The high presence of ketones, mainly 2-butanone, in the air of D and PD samples (Table 4) seems to confirm this report.

These results partially contrasted with how found for aerobic environment (composting). For example Eitzer (1995), reported during unsorted MSW-composting, the high presence of terpenes, but, also, the high presence of aromatic hydrocarbons. On the other hand VOCs emitted depended by the matrix composted. Komilis et al. (2004), studying VOCs emitted during composting of different organic matrices, showed for similar organic matrix used in this work, i.e., food waste, a different pattern of emission. Food waste composting emitted, mainly, sulphides, followed by acid/ester, alcohols, terpens but, also, aromatic hydrocarbon. Contrarily, when mixed waste (mix paper) was considered, aromatic of xenobiotic origin were, also, largely emitted.

When anaerobic environment, i.e., landfill, was studied (Eklund et al., 1998), gas composition differed from our study for the presence of the high concentration of aromatic hydrocarbons because of the presence unsorted MSW.

Nevertheless, Komilis et al. (2004) indicated that aromatic hydrocarbons were emitted even if only food waste were composted, suggesting further studied to investigate source of non-biogenic VOCs in MSW.

In this study aromatic hydrocarbon were detected, as well, but at very low concentration (Table 3 ) if compared with Komilis et al., data (Komilis et al., 2004). Aromatic hydrocarbons detected were, mainly, toluene and various alky-benzene that probably suggested a non-biogenic origin.

In conclusion differences occurred in different studies reported in the literature, depend by the process performed (aerobic vs anaerobic), by the different waste considered (unsorted MSW or food waste from source separated collection), by the different origin of the food waste because of different diet (Italy vs USA), and by the presence/absence of aeration that promoted volatile organic compound stripping from waste. 
When each class of molecules (Table 3 ) in the air waste was considered together with the olfactometric analyses, no significant $(P<0.05)$ correlations were found. Therefore, the organic molecules by themselves were not able to describe the odour emitted by the wastes. Gralapp et al. (2001) suggested that human odourous response (OU measurement) may be based on compounds that are not detected by GC-MS analysis or by the presence of synergic effects between different organic molecules.

Therefore, the synergistic effect and the complexity of the organic compounds in air, more than a single organic or inorganic compound, were responsible for the odour impact. Both the EN and GC-MS data, when successively elaborated by principal component analysis, allowed the description of organic molecules as a whole. Thus, it can be assumed that PCA and GC-MS elaboration allows the study of the complex effects of the organic molecules. In effect, when the sensor data from the EN analysis and the organic compound classes from GC-MS analysis were considered together by PCA analyses, and the results correlated with the odour unit by PLS analysis, good regressions were found for the EN (EN vs OU: $R^{2}=0.99, R_{\mathrm{cv}}^{2}=0.95 ; P<0.01$, sensors selected: $\left.\mathrm{S} 1-\mathrm{S} 7\right)$ but lower for the GC-MS data (GC-MS vs OU: $R^{2}=80, R_{\mathrm{cv}}^{2}=0.40 ; P<0.01$, organic compounds selected: esters).

Therefore, the EN and though much less, GC-MS were able to describe the odour impact of the waste by multivariate statistical analysis. Above all, after correct calibration, the EN could replace olfactometry as a tool for odour impact measurement (Defoer et al., 2002). The olfactometry approach, despite being the accepted method for determining odour concentration (CEN, 2003) in air, has as its main drawback the fact that it must be conducted in a controlled laboratory setting and a sufficient number of panelists must be available to conduct the analysis. Moreover, during the olfactometric session, the panelists are required to inhale environmental air samples that might contain hazardous compounds.

\section{Conclusion}

The acquirement of biological stability due to organic matter degradation reduces much of the odour impact of the OFMSW (digestate). Therefore, the measurement of the biological stability by the determination of the oxygen uptake rate $\left(\mathrm{OD}_{20}\right)$ could be used as a first indication of the potential odour impact of the digestate such as the good regressions found for $\mathrm{OD}_{20}$ vs both EN and GCMS data confirmed.

\section{Acknowledgements}

Mr. G. Bianchi is gratefully acknowledged for his help in GC-MS analysis.

This study was supported by Lombardy Region and ARAL, Italy (National Program for Biofuels - ProBio Biogas).

\section{Appendix A. Supplementary material}

Supplementary data associated with this article can be found, in the online version, at doi:10.1016/j.biortech.2010.04.098.

\section{References}

Adani, F., Gigliotti, G., Valentini, F., Laraia, R., 2003. Respiration index determination: a comparative study of different methods. Compost Sci. Util. $11,144-151$

APAT, 2003. Agenzia per la Protezione dell'Ambiente e per i Servizi tecnici. Metodi di misura delle emissioni olfattive, Manuali e linee Giuda 19, Roma, IT

APHA-American Public Health Association, 1998. Standard Methods for the Examination of Water and Wastewater, 20th ed. APHA, Washington, DC.

Barlaz, M.A., 2006. Forest products decomposition in municipal solid waste landfills. Waste Manage. 26, 321-333.
CEN, 2003. Air quality - determination of odour concentration by dynamic olfactometry, Standard method n. 13725, European Committee for Standardization, Brussels, B.

Davoli, E., Gangai, M.L., Morselli, L., Tonelli, D., 2003. Characterisation of odorants emissions from landfills by SPME and GC-MS. Chemosphere 51, 357-368.

Defoer, N., De Bo, I., Van Langenhove, H., Dewulf, J., Van Elst, T., 2002. Gas chromatography-mass spectrometry as a tool for estimating odour concentrations of biofilter effluents at aerobic composting and rendering plants. J. Chromatogr. 970, 259-273.

D’Imporzano, G., Crivelli, F., Adani, F., 2008. Biological compost stability influences odor molecules production measured by electronic nose during food-waste high-rate composting. Sci. Total Environ. 402, 278-284.

Edelmann, W., Baier, U., Engell, H., 2005. Environmental aspects of the anaerobic digestion of the organic fraction of municipal solid wastes and of solid agricultural wastes. Water Sci. Technol. 52, 203-208.

Eitzer, B.D., 1995. Emissions of volatile organic chemicals from municipal solid waste composting facilities. Environ. Sci. Technol. 29, 896-902.

Einax, J.W., Zwanziger, H.W., Geiß, S., 1997. Chemometrics in Environmental Analysis. VCH Edition, Weinheim, D.

Eklöv, T., Johansson, G., Winquist, F., Lundström, I., 1998. Monitoring sausage fermentation using an electronic nose. J. Sci. Food Agric. 76, 525-532.

Eklund, B., Anderson, E.P., Walker, B.L., Burrows, D.B., 1998. Characterization of landfill gas composition at the fresh kills municipal solid-waste landfill. Environ. Sci. Technol. 32, 2233-2237.

Ferrer, I., Ponsá, S., Vázquez, F., Font, X., 2008. Increasing biogas production by thermal $\left(70^{\circ} \mathrm{C}\right)$ sludge pre-treatment prior to thermophilic anaerobic digestion. Biochem. Eng. J. 42, 186-192.

Fredriksson, H., Baky, A., Bernesson, S., Nordberg, A., Noren, O., Hansson, P.A., 2006. Use of on-farm produced biofuels on organic farms - evaluation of energy balances and environmental loads for three possible fuels. Agric. Syst. 89, 184-203.

Fricke, K., Santen, H., Wallmann, R., 2005. Comparison of selected aerobic and anaerobic procedures for MSW treatment. Waste Manage. 25, 799-810.

Gralapp, A.K., Powers, W.J., Bundy, D.S., 2001. Comparison of Olfactometry, Gas Chromatography and Electronic Nose Technology for Measurement of Indoor Air from Swine Facilities. American Society of Agricultural Engineers, St. Joseph, MI.

IRSA CNR, 1994. Metodi analitici per le acque, Quaderni N. 100. Istituto Poligrafico e Zecca dello Stato, Roma, IT

Komilis, D.P., Ham, R.K., Park, J.K., 2004. Emission of volatile organic compounds during composting of municipal solid wastes. Water Res. 38, 1707-1714.

Lasaridi, K.E., Stentiford, E.I., 1998. A simple respirometric technique for assessing compost stability. Water Res. 32, 3717-3723.

Lissens, G., Vandevivere, P., De Baere, L., Bley, E.M., Verstraete, W., 2001. Solid waste digesters: process performance and practice for municipal solid waste digestion. Water Sci. Technol. 44, 91-102.

Moller, J., Boldrin, A., Christensen, T.H., 2009. Anaerobic digestion and digestate use: accounting of greenhouse gases and global warming contribution. Waste Manag. Res. 27, 813-824.

Pierucci, P., Porazzi, E., Martinez, M.P., Adani, F., Carati, C., Rubino, F.M., Colombi, A., Calcaterra, E., Benfenati, E., 2005. Volatile organic compounds produced during the aerobic biological processing of municipal solid waste in a pilot plant. Chemosphere 59, 423-430.

Pognani, M., D'Imporzano, G., Scaglia, B., Adani, F., 2009. Substituting energy crops with organic fraction of municipal solid waste for biogas production at farm level: a full-scale plant study. Process Biochem. 44, 817-821.

Rosenfeld, P.E., Suffet, I.H., 2004. Understanding odorants associated with compost, biomass facilities, and the land application of biosolids. Water Sci. Technol. 49, 193-199.

Schievano, A., Pognani, M., D’Imporzano, G., Adani, F., 2008. Predicting anaerobic biogasification potential of ingestates and digestates of a full-scale biogas plant using chemical and biological parameters. Bioresour. Technol. 99, 8112-8117.

Smet, E., Van Langenhove, H., De Bo, I., 1999. The emission of volatile compounds during the aerobic and the combined anaerobic/aerobic composting of biowaste. Atmos. Environ. 33, 1295-1303.

Staley, B.F., Xu, F., Cowie, S.J., Barlaz, M.A., Hater, G.R., 2006. Release of trace organic compounds during the decomposition of municipal solid waste components. Environ. Sci. Technol. 40, 5984-5991.

Tambone, F., Genevini, P.L., D'Imporzano, G., Adani, F., 2009. Assessing amendment properties of digestate by studying the organic matter composition and the degree of biological stability during the anaerobic digestion of the organic fraction of MSW. Bioresour. Technol. 100, 3140-3142.

Tani, M., Sakamoto, N., Kishimoto, T., Umetsu, K., 2006. Utilization of anaerobically digested slurry combined with other waste following application to agricultural land. Int. Congr. Ser. 1293, 331-334.

Termonia, A., Termonia, M., 1999. Characterization and on-site monitoring of odorous organic compounds in the environment of a landfill site. Intern. J. Environ. Anal. Chem. 73, 43-57.

Tsai, C.J., Chen, M.L., Ye, A.D., Chou, M.S., Shen, S.H., Mao, I.F., 2008. The relationship of odor concentration and the critical components emitted from food waste composting plants. Atmos. Environ. 42, 8246-8251.

US Department of Agriculture - US Composting Council, 2002. Test Methods for the Examination of Composting and Compost (TMECC). Edapho International, Houston, TX.

Widdel, F., 1986. Growth of methanogenic bacteria in pure culture with 2-propanol and other alcohols as hydrogen donors. Appl. Environ. Microb. 51, 1052-1062.

Zhang, R., El-Mashad, H.M., Hartman, K., Wang, F., Liu, G., Choate, C., Gamble, P., 2007. Characterization of food waste as feedstock for anaerobic digestion. Bioresour. Technol. 98, 929-935. 